\title{
OVERTOURISM PHENOMENON AT BOROBUDUR TEMPLE BASED ON THE PENTA HELIX PERSPECTIVES
}

\author{
Ersya Fadilla Rachmat ${ }^{1}$, Anang Sutono ${ }^{2}$, Renalmon Hutahaean ${ }^{3}$ \\ Bandung Tourism Institute, Jl. Dr. Setiabudi No.186, Bandung, West Java 40141 \\ Email: 1ersyafadilla@gmail.com, 2anang@stp-bandung.ac.id, ${ }^{3}$ reh@stp-bandung.ac.id
}

\begin{abstract}
The purpose of this research is to identify the overtourism issues at Borobudur Temple based on Penta Helix's perspectives. There is 5 kind of issues that will be identified based on Peeter et al (2018) such as issues related to tourist number, issues related to physical or build environment, socio-cultural issues, socio-economic issues and tourist perception based on Penta Helix perspectives. The empirical condition happened that many events like Borobudur Symphony, Concert Marathon, and the liked conducted in the area of Borobudur Temple. This study used qualitative research. Researchers wanted to understand the phenomena of certain social conditions that occurred in the research place. To identify the overtourism phenomenon in destination, the interview was conducted with each stakeholder according to Penta Helix elements which consist of academicians, business, community, government, and media. By interviewing each of Penta Helix elements, comprehensive findings can be produced following the 5 kinds of issues mentioned. According to each stakeholder by the Penta Helix model, there are some overtourism phenomena or issues that already happened in the destination. Those are issues related to tourist numbers, physical and built environment, socio-cultural issues, and tourist perception. And one of the issues that have not happened in the destination is socio-economic issues.
\end{abstract}

Keywords: Overtourism, Destination, Phenomenon, Penta Helix, Tourist Perception.

\section{A. INTRODUCTION}

The development of tourism in the world has increased rapidly with the number of tourists increasing from year to year. According to UNWTO (2018: 4) in the last few decades, tourists who travel internationally in 1950 were 250 million people and became more than 1.3 billion in 2017 . UNWTO also estimates that this number will grow by 3.3\% every year which in the end in 2030 will more than 1.8 billion tourists who travel. The increasing number of tourists traveling will certainly increase the number of visits to various destinations around the world (UNWTO, 2018: 4). The increasing number of tourists around the world has a positive impact on the number of visits to tourism destinations and also has a negative impact on local residents. One of the consequences that occur as a result of the increasing number of visitors to a destination is the discomfort of the local population caused by too many tourists or it can be called overtourism or tourism phobia (UNWTO, 2018: 4).

According to Skift (2016), mention that overtourism can be defined as "the impact of tourism on a destination, or parts thereof, that excessively influences perceived quality of life of the citizen and/or quality of visitors experiences in a negative way". Overtourism is a new term used in the world of tourism. According to Dodds and Butler (2019: 1), this term was first used in 2006 by the online skift community which discusses the negative impacts that occur in tourist destinations. Overtourism has been studied in several well-known tourist destinations in the world, such as in 13 cities in Europe (Koens et al, 2018: 1). Overtourism is a phenomenon that can occur anywhere, both in urban areas, rural areas, and island destinations (Koens et al, 2018: 10). Therefore, overtourism can also occur in famous tourist destinations in Indonesia.

\footnotetext{
* Corresponding author

Received: March 05, 2021; Revised: May 19,2021; Accepted: May 20, 2021
} 
Indonesia has many world-famous destinations, one of which is the Borobudur Temple. This tourist destination is one of the super-priority destinations that are being developed in order to bring more tourists. Until now, there are quite a lot of visitors come to Borobudur Temple, there were 3,855,285 tourists in 2018 (Statistics of Magelang Regency 2018). Several national and international events are also frequently held such as the Borobudur Marathon as a sports event and music concerts such as the Borobudur Nite and Borobudur Symphony in 2019. A large number of visitors, events, as well as destination development plans aimed at increasing the number of tourists. These, of course, can have a positive impact and can also have a negative impact such as the phenomenon of overtourism which can be observed in a destination, Koens et al (2018: 9) said that "Overtourism is predominantly observed in (increasingly) popular parts of the city, at a certain time or during certain events". Meanwhile, the phenomenon of overtourism will occur when in a tourist destination there are several phenomena such as related to the number of tourists, the physical and built environment, socio-cultural, socio-economic, and tourist perceptions (Peeter et al, 2018: 37).

According to UNWTO (2018: 7), handling overtourism cannot be seen only from changes in the number of tourists and tourist behavior but also from stakeholders. Dodds and Butler, (2019: 1) stated that the term "overtourism" has rapidly gained traction across multiple sectors, including academia, policy formulation, social movements, and the media. This shows the importance of the role of stakeholders in the phenomenon of overtourism. Arif Yahya (2016 in Yuniningsih et al, 2018: 87) states that there are 5 elements of tourism stakeholders consisting of academia, business, community, government, and media which is called Penta Helix. According to the Director of Tourism Marketing BOB (Borobudur Authority Agency). Borobudur Temple has a capacity of 128 people per day or 21,120 people per year. But in 2018, Borobudur Temple tourists nearly reached 4 million visitors. Borobudur Temple also has many events such as the Borobudur Marathon with more than 41 thousand visitors a day, the Borobudur Symphony which is attended by international artists which can bring thousands of tourists, and the Borobudur Nite concert which is attended by many tourists. The large number of tourists who come either as tourists who only enjoy Borobudur Temple or attend events that are held is certainly one of the factors that can cause the phenomenon of overtourism at Borobudur Temple. Based on the explanation above, this research Overtourism Phenomenon in Borobudur Temple from the Perspective of Penta Helix.

\section{Overtourism}

Recently, the studies of the overcrowdedness of tourists in popular destinations have been rapidly growing. Those indicate more and more research results related to the quality of services in a tourism destination. Milano et al (2018 in Dodds dan Butler 2019:1) state that overtourism is the excessive growth of visitors leading to overcrowding in areas where residents suffer the consequences of temporary and seasonal tourism peaks, which have enforced permanent changes to their lifestyles, access to amenities and general well-being. It is clearly relevant to the empirical condition that happened in Borobudur Temple Destination. This kind of circumstance influence the authenticity of the cultural and environmental living of the people around the Borobudur Temple.

According to Goodwin (2017 in Dodds dan Butler 2019:1), said that destination experiences overtourism when people in a destination or tourists feel that too many tourists are reducing the quality of life of the surrounding community and reducing the quality of the tourist experience that is no longer acceptable. Those statements appropriate to what is worried by tourism stakeholders around the Borobudur Temple. The Truth is the quality of tourist experiences decreasing time by time.

Higgins-Desbiolles (2019: 6) states that overtourism is a situation where a tourist destination exceeds it is carrying capacity either physical and psychological. This is due to the reduced quality experiences of both tourists and local communities. If this is the case continues without supervision then 
overtourism will bring serious consequences for popular destinations. In fact, the ecosystem of tourism in the surrounding of Borobudur Temple has been disturbed by a bigger and bigger number of tourist visitors.

Peeter et al (2018:15) said that overtourism describes the situation in which the impact of tourism, at certain times and in certain locations, exceeds physical, ecological, social, economic, psychological, and/or political capacity thresholds. In conjunction with the condition of the Borobudur Temple, the multieffects have been real and arising the serious challenges to all stakeholders most specifically in terms of the Penta Helix clusters.

\section{Overtourism Issues}

Dodds dan Butler (2019:1) states that the concerns about overtourism expressed in both academic and popular literature include too many tourists in one place, rowdy, and other inappropriate behavior by tourists antagonism between residents and tourists, crowding, strains on infrastructure. The fact that this kind of overtourism expression has happened in Borobudur Temple. It is definitely expressing the curioucity of how the overtourism in Borobudur Temple should be well anticipated. According to Peeter et al (2018:37) destination manager outlined a number of specific overtourism issues are: 1). Issues related to tourist numbers were the ratio of tourists to local residents, the impact of Airbnb on residential housing markets, visitation of specific attractions, 2). Issues related to the physical or built environment included erosion and noise in protected areas, littering and waste generation, traffic density, the decline in traffic safety, and freshwater and electricity demand growth, 3). Socio-cultural issues included change in place identity, local tensions, antisocial behavior of tourists, filming and taking photographs of native people, 4). Socio-economic issues included a decline in services for local residents, infrastructure predominantly and increasingly catering to tourists, residents forced out of certain areas in larger cities, employees in tourism facing less favorable working conditions, the rising cost of food and beverage for locals, and the influx of foreign labor as a result of seasonally high labor demand, 5). Tourist perspective on tourist included perception of crowdedness.

Table I. Indicator of Overtourism Issues

\begin{tabular}{|c|c|c|c|c|}
\hline $\begin{array}{l}\text { Issues } \\
\text { related to } \\
\text { tourist } \\
\text { numbers }\end{array}$ & $\begin{array}{l}\text { Issues related to } \\
\text { the physical or } \\
\text { built } \\
\text { environment }\end{array}$ & $\begin{array}{l}\text { Socio-cultural } \\
\text { issues }\end{array}$ & $\begin{array}{l}\text { Socio-economic } \\
\text { issues }\end{array}$ & $\begin{array}{l}\text { Tourist } \\
\text { perspective } \\
\text { on tourist }\end{array}$ \\
\hline Crowding & $\begin{array}{l}\text { Erosion and noise } \\
\text { in the protected } \\
\text { area }\end{array}$ & $\begin{array}{l}\text { Rowdy and } \\
\text { inappropriate } \\
\text { behavior by } \\
\text { tourists }\end{array}$ & Loss of amenity & $\begin{array}{l}\text { Loss of } \\
\text { authenticity }\end{array}$ \\
\hline $\begin{array}{l}\text { Too many } \\
\text { tourists in one } \\
\text { place }\end{array}$ & $\begin{array}{l}\text { Littering and } \\
\text { waste generation }\end{array}$ & $\begin{array}{l}\text { Antagonism } \\
\text { between tourist } \\
\text { and residents }\end{array}$ & $\begin{array}{l}\text { The decline of } \\
\text { services for local } \\
\text { residents }\end{array}$ & $\begin{array}{l}\text { Perception of } \\
\text { crowdedness }\end{array}$ \\
\hline $\begin{array}{l}\text { The ratio of } \\
\text { tourist to local } \\
\text { residents }\end{array}$ & Traffic density & $\begin{array}{l}\text { Reduction in } \\
\text { quality of life of } \\
\text { residents }\end{array}$ & $\begin{array}{l}\text { Infrastructure } \\
\text { predominantly and } \\
\text { increasingly } \\
\text { catering to the } \\
\text { tourist }\end{array}$ & \\
\hline $\begin{array}{l}\text { Impact of } \\
\text { Airbnb on } \\
\text { residential }\end{array}$ & $\begin{array}{l}\text { The decline in } \\
\text { traffic safety }\end{array}$ & $\begin{array}{l}\text { Changes in place } \\
\text { identity }\end{array}$ & $\begin{array}{l}\text { Employees in } \\
\text { tourism facing less }\end{array}$ & \\
\hline
\end{tabular}

50 Jurnal Kepariwisataan: Destinasi, Hospitalitas dan Perjalanan, Volume 5 Nomor 1, 2021: 48-57 


\begin{tabular}{lllll}
$\begin{array}{l}\text { Issues } \\
\text { related to } \\
\text { tourist } \\
\text { numbers }\end{array}$ & $\begin{array}{l}\text { Issues related to } \\
\text { the physical or } \\
\text { built } \\
\text { environment }\end{array}$ & $\begin{array}{l}\text { Socio-cultural } \\
\text { issues }\end{array}$ & $\begin{array}{l}\text { Socio-economic } \\
\text { issues }\end{array}$ & $\begin{array}{l}\text { Tourist } \\
\text { perspective } \\
\text { on tourist }\end{array}$ \\
\hline $\begin{array}{l}\text { housing } \\
\text { markets }\end{array}$ & & & $\begin{array}{l}\text { favorable working } \\
\text { conditions }\end{array}$ \\
\hline $\begin{array}{l}\text { Visitation of } \\
\text { specific } \\
\text { attractions }\end{array}$ & $\begin{array}{l}\text { Freshwater and } \\
\text { electricity } \\
\text { demand growth }\end{array}$ & Local tensions & $\begin{array}{l}\text { The rising cost of } \\
\text { food and beverages } \\
\text { for local }\end{array}$ \\
\hline
\end{tabular}

Source: Dodds dan Butler (2019:1) dan Peeter et al (2018:37)

Those are some of the indicators for destinations that already experiencing overtourism, and those indicators indicated that the Borobudur Temple should be looked after by a comprehensive and incorporated all stakeholders.

\section{Penta Helix}

Penta Helix, Penta is five, and helix means the elements that hold each other tightly. The Penta Helix is a five-strong elemental bond that binds each other consisting of ABCGM elements, namely Academician, Business, Community / Society, Government, and Media. The Penta helix model is a development of the previous model, namely the triple helix, namely elements of government, industry, and universities (Sutono, 2020). The fact that fundamental parts of managing the Borobudur Temples have not been approached and delivered by the holistic and comprehensive elements called Penta Helix.

According to Peeter et al (2018: 21) perspectives on overtourism may include those on various stakeholders, such as residents, tourists, or businesses that means that perspectives about overtourism involving stakeholders. Finally, it is approved that the Borobudur Temple has not been managed properly and gives rise to the negative impact called overtourism.

\section{B. RESEARCH METHOD}

This research used a qualitative descriptive method. According to Moleong (2016: 6), qualitative research is research that intends to understand the phenomena experienced by research subjects such as behavior, motivation, action, etc. Qualitative research has a flexible research design in order to adapt the plan to the symptoms in the actual research location (Sujarweni, 2019: 26). In this study, the researcher wanted to understand the phenomena of certain social conditions that occurred in the research place.

This research was conducted in Borobudur Temple, Borobudur District, Magelang Regency, Central Java. Participants in this study were the representatives of each stakeholder in the Penta Helix Model.

\section{Table II. Participants of Each Stakeholder}

\begin{tabular}{ll} 
Stakeholder & \multicolumn{1}{c}{ Participant } \\
\hline Academia & Sekolah Tinggi Pariwisata Ambarukkmo Yogyakarta (STIPRAM) \\
\hline Business & Hotel Saraswati \\
\cline { 2 - 2 } & Ansor's Silver Mungkid \\
\hline Community & Himpunan Pramuwisata Indonesia Sleman \\
\hline Government & $\begin{array}{l}\text { Badan Otorita Borobudur } \\
\text { Dinas Pariwisata, Pemuda dan Olahraga Kabupaten Magelang }\end{array}$ \\
\hline Media & $\begin{array}{l}\text { Kedaulatan Rakyat Jogjakarta } \\
\text { Source: Processed data, 2020 }\end{array}$
\end{tabular}


Data collection techniques in this research were through interviews, and documentation studies, as well as data collection tools used, were interview guidelines, and related documents. The researchers did a deeper interview using snowball methods. The researchers used the reduction of data, presenting data, and data inference for analysis. According to Moleong (2016: 324) in determining the validity of the data, an inspection technique is needed. In this study, researchers used triangulation to check the validity of the data.

\section{RESULTS AND ANALYSIS}

Based on interviews with stakeholders, there are some of overtourism issues indicators that the destination already experienced. Those are:

Table III. Findings of Overtourism Issues

\begin{tabular}{|c|c|c|c|c|c|}
\hline $\begin{array}{c}\text { Overtourism } \\
\text { issues based on } \\
\text { Penta Helix } \\
\text { Perspectives }\end{array}$ & Academia & Business & Community & Government & Media \\
\hline $\begin{array}{l}\text { Issues related to } \\
\text { tourist numbers }\end{array}$ & $\begin{array}{l}\text { The crowd } \\
\text { happens in a } \\
\text { certain } \\
\text { cluster of } \\
\text { area }\end{array}$ & $\begin{array}{l}\text { The crowd } \\
\text { is } \\
\text { intolerable } \\
\text { numbers }\end{array}$ & $\begin{array}{l}\text { The crowd } \\
\text { happens in } \\
\text { intolerable } \\
\text { numbers }\end{array}$ & $\begin{array}{l}\text { The crowd } \\
\text { happens in } \\
\text { intolerable } \\
\text { numbers }\end{array}$ & $\begin{array}{l}\text { The crowd } \\
\text { happens in } \\
\text { intolerable } \\
\text { numbers }\end{array}$ \\
\hline $\begin{array}{l}\text { Issues related to } \\
\text { the physical or } \\
\text { built } \\
\text { environment }\end{array}$ & $\begin{array}{l}\text { Worried } \\
\text { about the } \\
\text { erosion, } \\
\text { noise, and } \\
\text { traffic density }\end{array}$ & $\begin{array}{l}\text { Influenced } \\
\text { only in } \\
\text { Traffic } \\
\text { density }\end{array}$ & $\begin{array}{l}\text { Erosion, } \\
\text { noise, and } \\
\text { traffic density } \\
\text { happens in an } \\
\text { intolerable } \\
\text { condition }\end{array}$ & $\begin{array}{l}\text { Erosion, } \\
\text { noise, and } \\
\text { traffic density } \\
\text { happens in an } \\
\text { intolerable } \\
\text { condition }\end{array}$ & $\begin{array}{l}\text { Erosion, noise, } \\
\text { and } \\
\text { traffic density } \\
\text { happens in an } \\
\text { intolerable } \\
\text { condition }\end{array}$ \\
\hline $\begin{array}{l}\text { Socio-cultural } \\
\text { issues }\end{array}$ & $\begin{array}{l}\text { Rowdy and } \\
\text { inappropriate } \\
\text { behavior of } \\
\text { tourists }\end{array}$ & $\begin{array}{l}\text { Has not } \\
\text { happened }\end{array}$ & $\begin{array}{l}\text { Rowdy and } \\
\text { inappropriate } \\
\text { behavior of } \\
\text { tourists }\end{array}$ & $\begin{array}{l}\text { Has not } \\
\text { happened }\end{array}$ & $\begin{array}{l}\text { Rowdy and } \\
\text { inappropriate } \\
\text { behavior of } \\
\text { tourists }\end{array}$ \\
\hline $\begin{array}{l}\text { Socio-economic } \\
\text { issues }\end{array}$ & $\begin{array}{l}\text { Has not } \\
\text { happened }\end{array}$ & $\begin{array}{l}\text { Has not } \\
\text { happened }\end{array}$ & $\begin{array}{l}\text { Has not } \\
\text { happened }\end{array}$ & $\begin{array}{l}\text { Has not } \\
\text { happened }\end{array}$ & $\begin{array}{l}\text { Has not } \\
\text { happened }\end{array}$ \\
\hline $\begin{array}{l}\text { Tourist } \\
\text { perspective on } \\
\text { overtourism }\end{array}$ & $\begin{array}{l}\text { Has not } \\
\text { happened }\end{array}$ & $\begin{array}{l}\text { Has not } \\
\text { happened }\end{array}$ & $\begin{array}{l}\text { Perception of } \\
\text { crowdedness }\end{array}$ & $\begin{array}{l}\text { Has not } \\
\text { happened }\end{array}$ & $\begin{array}{l}\text { Perception of } \\
\text { crowdedness }\end{array}$ \\
\hline
\end{tabular}

Source: Processed data, 2020

Those findings are related to the fundamental perspectives base on the Penta Helix elements. It can be found those perspectives are always related and connected to each other and it can be seen that the various opinions from the Penta Helix elements describe the slicing of spreaded opinion.

\section{Issues related to tourist number based on Penta Helix perspectives}

The phenomenon of overtourism related to the number of tourists according to three of the five elements of the Penta Helix (community, government, and media), the physical building of Borobudur Temple is a historical building that has limited capacity so that the government and community think that managers should be more disciplined in implementing restrictions on visitors according to the number that has been determined by the Borobudur Conservation Center and it is 128 people at a time. Meanwhile, according to academics, Borobudur Temple has not 
experienced crowding, not by seeing the number of tourists but because they think PT.TWC can manage it well, academics feel that the issues regarding too many tourists at Borobudur Temple can be well controlled by the manager.

Even so, academics admit that in the physical building of Borobudur Temple itself there has been a buildup of tourists which then PT.TWC built several facilities and activities in Zone II with the aim of reducing the number of tourists visiting Zone I, this proves that there is a buildup of tourists in Zone I. There are indicators in the form of visitations to specific attractions (Peeter et al, 2018: 37). Meanwhile, according to the business sector, the phenomenon of overtourism related to the number of tourists has not occurred because the more tourists who come to the destination the more profitable the business will be. Meanwhile, other indicators such as the ratio of tourists to local residents or the ratio of the number of tourists and local people have not occurred at Borobudur Temple. This is agreed to be said by the four elements of the Penta Helix namely academics, business, community, and government.

Then, according to Peeter et al (2018: 37), one indicator of the phenomenon of overtourism regarding the number of tourists is the impact of Airbnb on residential housing markets were due to the increasing number of accommodations needs, there have been many types of Airbnb which have become competitors to conventional accommodation businesses. This has not happened around Borobudur Temple. The accommodation business has its own market segment, this is in line with what is said by the community and the media that accommodation businesses like Airbnb actually help market homestays around Borobudur Temple.

Therefore, from several indicators mentioned by Peeter et al (2018: 37) or Dodds and Butler (2019: 1) that the phenomenon of overtourism is related to the number of tourists in Borobudur Temple that has occurred, namely crowding (Dodds and Butler, 2019: 1) and visitation in specific attractions (Peeter et al, 2018: 37) or it can also be called too many tourists in one place (Dodds and Butler, 2019: 1).

Based on the perspectives of tourists number, all Penta Helix elements agreed in the same boat that the over crowdness of tourists in the area Borobudur Temple was intorable numbers. It means that the relevant strategic action shall be taken in to account to avoid the quality of experiences are getting worse.

\section{Issues related to the physical or built environment}

The phenomenon of overtourism is related to the physical or built environment according to three of the five elements of the Penta Helix, namely community, government, and media, there are erosion and noise in protected areas (Peeter et al, 2018: 37).

They agree that Borobudur Temple is a noble cultural heritage in which any efforts are needed to protect to make it well conserved. The large number of tourists who go to the physical building of the temple is feared that it will cause erosion. In addition, the media also believes that large events such as concerts held around Borobudur Temple with loud music volume will have a negative impact on the physical building of the temple. This phenomenon according to Dodds and Butler (2019: 1) is also one of the overtourism phenomena in the form of noise which is an indicator of overtourism in a destination.

Apart from erosion and noise in protected areas, the business and community sectors also highlight the tremendous traffic jams during peak season and illegal parking which is very rampant. According to Peeter et al (2018: 37), this indicates the occurrence of traffic density or one of the indicators which states that the phenomenon of overtourism occurs when there is traffic density which can be in the form of traffic jams and parking disturbances. This is in line with what happened at the research location that the phenomenon of traffic jams occurs, especially during the peak season and rampant illegal parking.

Therefore, according to the three elements of the Penta Helix (community, government, and media), there has been a phenomenon of overtourism related to the physical and artificial 
environment in the form of erosion and noise in protected areas and traffic density according to the two elements of the Penta Helix, namely business and community. There is a need to analyze the impact of each tourism activity that exist both currently in progress and which will be generated further by considering the impacts on the environment (Pratiwi, Y. P., \& Sutono, A. et.al. 2019).

This is the fact finding that the physical and built environment were disturbing by the over crowdness of tourist visitor. Those elements of Penta Helix shall align and strengthen the commitment to minimize the damage of the buildings and environment around Borobudur Temple.

\section{Social-cultural issues}

According to Penta Helix, the phenomenon of overtourism related to the socio-culture of Borobudur Temple has not yet occurred which causes the local community to reject tourism. Because on the other hand, the local community is happy and feels benefited. Meanwhile, the phenomena that have occurred are those that involve tourists. According to three of the five elements of the Penta Helix (academics, media, and community), there are tourists who have not obeyed the rules and manners in the temple such as often relying on one point of the crowd and still occupying temple stones which is actually strictly prohibited by the managers.

Then indicators such as a change in place identity (Peeter et al, 2018: 37) or a change in the identity of a destination have not occurred at Borobudur Temple because Borobudur Temple is still being visited because of its image as a cultural heritage destination and there has not been any change in this.

The perspective of the five elements of Penta Helix explains that the relationship between the surrounding community and tourists is fine and actually beneficial. Other indicators concerning the mismatch between tourists and the community such as local tensions, antisocial behavior of tourists, and filming and taking photographs of native people (Peeter et al, 2018: 37), the antagonism between residents and tourists, and reduction in quality of life of residents has yet to occur at Borobudur Temple.

Therefore, the only overtourism phenomenon that occurs at Borobudur Temple is rowdy and inappropriate behavior of tourists (Dodds and Butler, 2019: 1) or inappropriate behavior by tourists.

\section{Socio-economic issues}

The phenomenon of overtourism related to socio-economy according to the five elements of the Penta Helix has not yet occurred because according to academics, business, community, government, and the media, the existence of tourism is very helpful for the economy of the surrounding community so that there has been no overtourism phenomenon and it is even stated that the impact is still not optimal and equitable for local residents, for example, there are the poorest villages in Central Java which are located about $2 \mathrm{~km}$ from Borobudur Temple.

Indicators of the phenomenon of overtourism mentioned by Peeter et al, 2018: 37 and Dodds and Butler, 2019: 1 will occur if the number of tourists is very large and in the end it is detrimental to the surrounding community, while the people around Borobudur Temple still feel greatly benefited by tourism at the temple Borobudur so the indicators of the phenomenon of overtourism related to socio-economic conditions have not occurred such as decline in services for local residents (shops, schools) (Peeter et al, 2018: 37) or reduced services to local communities such as shops or schools, infrastructure predominantly and increasingly catering to tourist (Peeter et al, 2018: 37) or infrastructure is dominated and increasingly only serves tourists, forced residents out of certain areas in larger cities (Peeter et al, 2018: 37) or local people are shifted to certain areas 
further away, employees in tourism facing less favorable woking conditions (Peeter et al, 2018: 37) or employees in tourism face unfavorable working conditions, the rising cost of food and beverages for locals or the increase in food and beverage prices for the local community.

The informant said that there is no increase in the price of drinks or food around Borobudur Temple because according to them the prices are still fairly normal. Then, the last one is the influx of foreign labor as a result of seasonally high labor demand or the entry of foreign workers as a result of the high demand for seasonal labor. This has not happened at Borobudur Temple because the average employee or employee is an Indonesian citizen except for the interests conservation which requires human resources from abroad. Therefore, the phenomenon of overtourism related to the socio-economy in Borobudur Temple according to the five elements of Penta Helix has not yet occurred.

\section{Tourist perception based on Penta Helix perspectives}

The phenomenon of overtourism is related to the perception of tourists at Borobudur Temple according to two of the five elements of the Penta Helix there are community and the media saying that tourists already feel that Borobudur Temple is too crowded especially during peak season. Community and media are one of the elements of the Penta Helix that are close to tourists because the community in this case is the community of tour guides who often take many tourists to Borobudur Temple and the media that are critical of reviews given by tourists. Meanwhile, the government considers that tourists still have a special interest in Borobudur Temple because it is one of the world cultural heritages, so tourists consider it natural that Borobudur Temple is very busy as well as businesses and academics who think that the average tourist has considered it reasonable and does not mind if the Temple is Borobudur is visited by many tourists, especially during peak season.

The indicator of the overtourism phenomenon is related to tourist perceptions, namely perception of crowdedness (Peeter et al, 2018: 37) because tourists according to the opinion of the community and the media already feel that Borobudur Temple is too crowded especially during peak season. However, other indicators such as loss of authenticity (Dodds and Butler, 2019: 1) have yet to occur because according to several informant tourists still see Borobudur Temple as having authenticity. Authenticity is a cultural heritage for tourists to visit.

Therefore, the phenomenon of overtourism in Borobudur Temple which is related to the perception of tourists have already occurred. It is what so called the perseption of crowdedness (Peeter et al, 2018: 37). It is indeed necessary to conduct further research on the phenomenon of overtourism from the perspective of tourists to prove it.

\section{CONCLUSION}

Based on the research results, it can be concluded that all elements of Penta Helix consisting of academics, business, community, government, and media in this study state that there have been several phenomena of overtourism in Borobudur Temple, including:

The phenomenon of overtourism related to the number of tourists at Borobudur Temple has occurred marked by several indicators of overtourism that have occurred at the research location, three of the five elements of the Penta Helix namely the community, government, and media agree that the number of tourists at Borobudur Temple is too much or the phenomenon of crowding. In addition, academics also mentioned that there was a buildup of tourists in the physical building of Borobudur Temple, namely the occurrence of visitations in specific attractions. 
The phenomenon of overtourism related to the physical or built environment has occurred. Marked by several indicators of overtourism that have occurred at the research site. Three of the five elements of Penta Helix namely the community, government, and media state that erosion and noise in protected areas have occurred (Peeter et al., 2018: 37). Then, the community and business also state that there has been traffic density (Peeter et al, 2018: 37) due to too many tourists.

The phenomenon of overtourism related to socio-culture at Borobudur Temple has occurred, indicated by several indicators of overtourism that have occurred in the research location. Three out of the five elements of Penta Helix namely academics, communities, and the media agree that there are indicators of rowdy and inappropriate behavior of tourists. Peeter et al, 2018: 37).

The phenomenon of overtourism related to the socio-economy at Borobudur Temple has not yet occurred, according to the opinion of all Penta Helix elements it can be concluded that there are no indicators of the socio-economic overtourism phenomenon that occurred in Borobudur Temple

The phenomenon of overtourism related to the perception of tourists at Borobudur Temple has occurred. Two of the five elements of Penta Helix namely the community and the media state that tourists have seen tourism in Borobudur Temple as too crowded (perception of crowdedness.

\section{E. SUGGESTION}

Based on the results of the research that has been concluded, the following are suggestions for Borobudur Temple to not experience the phenomenon of overtourism in the future including the phenomenon of overtourism, imposing restrictions on the number of tourists in accordance with the maximum number set, especially in Zone I of Borobudur Temple, adding more facilities in Zone II of Borobudur Temple to provide alternative activities so that tourists do not accumulate in one place, prioritizing conservation interests as a goal in tourism development at Borobudur Temple, improve services to tourists, especially during peak season. Further research It is necessary to conduct research that examines the application of visitor management at Borobudur Temple in order to be well conserved. Research on tourist perceptions of the phenomenon of overtourism in Borobudur Temple more specifically. Research on the economic, social and cultural impacts caused by the phenomenon of overtourism at Borobudur Temple.

\section{REFERENCES}

Bachri, B. S. (2010). "Meyakinkan Validitas Data Melalui Triangulasi Pada Penelitian Kualitatif." Jurnal Teknologi Pendidikan, 10 (1) 46-62.

Balai Konservasi Borobudur. (2016). "Info Cagar Budaya." kebudayaan.kemdikbud.go.id. https://kebudayaan.kemdikbud.go.id/bkborobudur/candi-borobudur/.

Dodds, R., and R. (Eds.) Butler. (2019). Overtourism: Issues, realities and solutions. Berlin: De Gruyter Oldenbourg.

Duignan, M. (2019). "Understanding and Managing Urban Tourism Growth beyond Perceptions: Cambridge Case Study: Strategies and Tactics to Tackle Overtourism." In 'Overtourism'? Understanding and Managing Urban Tourism Growth beyond Perceptions: Case Studies , 3439. United Nations World Tourism Organisation (UNWTO).

Guizi, A., Z. Breda, and R. Costa. (2020). "How are overtourism and host-guest relationships portrayed by the Portuguese print media?" International Journal of Tourism Cities.

Halibas, A. S., R. O. Sibayan, and R. L. R. Maata. (2017). "The Penta Helix Model Of Innovation In Oman: An Hei Perspective." Interdisciplinary Journal of Information, Knowledge \& Management 12.

Higgins-Desbiolles, F., S. Carnicelli, C. Krolikowski, G. Wijesinghe, and K. Boluk. (2019). "Degrowing tourism: rethinking tourism." Journal of Sustainable Tourism 27 (12) 1926 - 1944. 
Koens, K., A. Postma, and B. Papp. (2018). "is overtourism overused? Understanding the impact of tourism in a city context." Sustainability, 10(12) 4384.

Moleong, L. J. (2016). Metodologi Penelitian Kualitatif. Bandung: Rosda.

Noor Syifa, F. (2019). Peran Stakeholder Dalam Pengelolaan Kawasan Kota Lama Semarang, Jawa Tengah. Skripsi tidak diterbitkan. Bandung: Sekolah Tinggi Pariwisata Bandung.

Peeters, P. M., S. Gössling, J. Klijs, C. Milano, M. Novelli, C. H. S. Dijkmans, ..., and A. Postma. (2018). Research for TRAN Committee - Overtourism: impact and possible policy responses. European Parliament, Directorate General for Internal Policies, Policy Department B: Structural and Cohesion Policies, Transport and Tourism.

Perkumienè, D., and R. Pranskūnienè. (2019). "Overtourism: Between the right to travel and residents' rights." Sustainability 11(7), 2138.

Rahman, N., and H. B. S. Prakoso. (2012). "Perspektif Stakeholders Terhadap Potensi Obyek Dan Daya Tarik Wisata (ODTW) Telaga Ngebel Kabupaten Ponorogo." Jurnal Bumi Indonesia 1 (1).

Pratiwi, Y. P., \& Sutono, A. et.al. (2019). Tourism Activities Development Based on SustainableLivelihood Approach in The Tourism Villages ofPurwakarta Regency. Journal of Advances in Social Science and Humanities, JASSH 5 (2),588-591.

Saputri, F. W. (2020). Implementasi Model Penta Helix Dalam Pengembangan Pariwisata Studi Pada Talang Indah Fajaresuk Kab. Pringsewu. Skripsi tidak diterbitkan. Bandar Lampung: Universitas Lampung.

Sujarweni, V. W. (2019). Metodologi Penelitian. Yogyakarta: Pustaka Baru Press.

Sutono, Anang. 2020. Pariwisata dan Ketahan Nasional. Bandung: UPI Press.

Szromek, A. R., Z. Kruczek, and B. Walas. (2019). "The Attitude of Tourist Destination Residents towards the Effects of Overtourism-Kraków Case Study." Sustainability, 12(1) 1 - 17.

Yuningsih, T., T. Darmi, and S. Sulandari. (2019). "Model Pentahelik Dalam Pengembangan Pariwisata Di Kota Semarang." JPSI (Journal of Public Sector Innovations), 3(2) 84 - 93.

Żemła, M. (2020). "Reasons and Consequences of Overtourism in Contemporary Cities-Knowledge Gaps and Future Research." Sustainability, 12(5). 